\title{
Transnational Life in Multicultural Space: Azerbaijani and Tatar Discourses in Interwar Europe ${ }^{1}$
}

\author{
Zaur Gasimov and Wiebke Bachmann
}

Dans la période entre les deux guerres, la presse européenne dite d'information ne traitait que rarement des problèmes de l'Orient musulman. ${ }^{2}$

After a short intermezzo between 1918 and 1921, Soviet Russia was able to reconquer most of the territories of the former Tsardom in the Caucasus, the Ukraine, and in Central Asia, which became independent or at least self-ruled around 1917. The short-lived independent republics of Crimea, Azerbaijan, and Turkestan ${ }^{3}$ with their predominantly Muslim population were occupied by the Red Army, and then gradually sovietized. ${ }^{4}$ The Sovietization challenged the political elites of these countries dramatically. Those who survived the invasion of the Bolsheviks either had to accept the Communist regime or escape. Thousands of former politicians and intellectuals, both Shīa and Sunnīs, left for Turkey, France, Germany, and Poland. While living in exile many continued political, journalistic, and public activities writing against Communism, and protesting against the persecutions in the Soviet Union. At the same time, these intellectuals were eager to inform the society in their host countries about their countries of origin, which were left under Soviet occupation. Being quite well integrated into the intellectual milieus of interwar Paris, Warsaw, Berlin, and other European cities in the 1920s and 1930s, they were confronted with European realities, ideas, and views on Christianity and Islam.

1 All translations from Polish, Turkish, Azerbaijani, and German were done by the authors of the contribution.

2 Haidar Bammate, Visages de l'Islam (Lausanne: Payot, 1946), 1.

3 Here Turkestan refers to the geographic name of the region of Central Asia that was dominated by Russia until 1991.

4 For more on the period of the short-lived independence, see Firuz Kazemzade, The Struggle for Transcaucasia: 1917-1921 (Westport, Ст: Hyperion Press, 1981).

(C) ZAUR GASIMOV AND WIEBKE BACHMANN, 2016 | DOI 10.1163/9789004301979_010 
This article explores selected publications, articles, and booklets of several prominent Azerbaijani, ${ }^{5}$ northern Caucasian, and Tatar émigré intellectuals in interwar Europe, including Mehmed Emin Rasulzade (1884-1955), Hilal Munschi (1899-?), Ahmet Zeki Velidi Toğan (1890-1970), Haïdar Bammate (1890-1965), and Cafer Seydahmet (1889-1960); these works were published in Europe in Russian, Polish, French, and German. The analysis here focuses on the representation of Islam in the writings of these Muslim intellectuals. Born in the 1880s, all were graduates of Russian and European schools, belonged to the Muslim minority in the Russian Empire, and then spent decades exiled in Europe. Their sojourns in France, Poland, and Germany throughout the 1920s and 193os did not mean, therefore, a cultural watershed to their primary socialization. As Muslims they were aware of European culture while they lived in the Caucasus or the Crimea under Russian rule. ${ }^{6}$

Socialized under the circumstances of the imperial homogenization 'from above' and certain cultural resistance strategies of non-Russian peripheries and educated in imperial high schools and universities, these intellectuals combined the awareness of Russian, Near Eastern, and European traditions and cultures. It is easier to define them as entangled intellectuals who were rooted in several civilizations, than to try to classify them merely as Azerbaijani, Tatar or Muslim intellectuals in interwar Europe. They represented a multicultural hybridity: ${ }^{7}$ They lived and were active in the special intellectual space of interwar Europe. ${ }^{8}$

5 For more detail on Azerbaijani émigrés in Europe in general and in Germany in particular, see Zaur Gasimov and Wiebke Bachmann, “Für nationale Ehre, Freiheit und Selbständigkeit!' Die publizistische Aktivität der aserbaidschanischen Exilanten in Berlin in der Zwischenkriegszeit," in Brücken bauen-Analysen und Betrachtungen zwischen Ost und West. Festschrift für Leonid Luks zum 65. Geburtstag, ed. Jürgen Zarusky, et al. (Stuttgart: Ibidem Verlag, 2012), 277-294.

6 We argue that at least the urban spaces of the Russian Empire, like Moscow, St. Petersburg, Kazan, Kiev, Odessa, Baku, Bakhchesaray, and Tbilisi can be considered European. Therefore, intellectuals who resettled from St. Petersburg to Paris or from Baku to Warsaw still moved within a European cultural space.

7 In this context the term of hybridity is borrowed from the post-colonialist debates initiated by Homi Bhabha.

8 It is difficult, however, to define this intellectual space as the "third space," in Homi Bhabha's terms. Being in Europe and therefore outside the territory of the Russian Empire and the UssR, Bhabha's third space is hardly applicable with regard to the study of Russian Muslims who migrated to Europe. See Jonathan Rutherford's interview with Homi Bhabha: "The Third Space. Interview with Homi Bhabha," in Identity: Community, Culture, Difference, ed. Jonathan Rutherford (London: Lawrence and Wishart, 1990), 207-221. 
In this context, we investigate the role of Islam as an important element of the self-identification and national identity of these intellectuals. How did the Muslim intellectuals from the former Russian Tsardom react to the European visions and ideas of Islam? How did they eventually try to influence, or 'revise' these conceptions? And how important was Islam to their life in exile and in which regard?

Moreover the correlation of the representation of Islam and, for example, anti-communism, which was the main political focus of these intellectuals in interwar Europe, is taken into consideration. The classification of these Muslim intellectuals in interwar Europe as entangled intellectuals ${ }^{9}$ offers a theoretical approach to historical entanglements and therefore an additional key to understanding the specific representation of Islam under the circumstances of exile.

\section{Entangled Intellectuals}

The entangled intellectuals Mehmed Emin Rasulzade, Hilal Munschi, Zeki Velidi Toğan, Haïdar Bammate, and Cafer Seydahmet were born in different parts of the Russian Tsardom but nevertheless were confronted with the same or at least similar experiences in the peripheries of the empire. As a result of the primary educational socialization in Russian schools they were fluent in Russian and had a good knowledge of Russian culture and literature. The period of their childhood and socialization at the secondary, and high schools that they attended coincided with the severe russification strategy under Tsar Alexander III and Nicolas I at the end of the nineteenth century. ${ }^{10}$ In the same space of time the conservative pan-Slavist ideology was quite widespread in Moscow and St. Petersburg. The Russian pan-Slavist discourse had distinct anti-Turkish and anti-Muslim elements. ${ }^{11}$ Pan-Slavist ideologists, for example,

For the notion of the "entangled intellectual," see Zaur Gasimov, "Bolshevik PostColonialism, Eurasian Perspective and Entangled Intellectuals. Russian Debates on Spengler in the Interwar Period," in Oswald Spengler als europäisches Phänomen. Der Transfer der Kultur- und Geschichtsmorphologie im Europa der Zwischenkriegszeit 19191939, ed. Zaur Gasimov and Carl A. Lemke Duque (Göttingen: V\&R, 2013), 79.

10 For more on russification, see Theodore R. Weeks "Russification/Sovietization," in European History Online (EGO) (Mainz: Institute of European History (IEG), 2010). Accessed 2 Dec. 2013: http://ieg-ego.eu/en/threads/models-and-stereotypes/russification -sovietization.

11 For more on pan-Slavism, its agents, and variety, see the compendium: Post-Panslavismus. Slavizität, Slavische Idee und Antislavismus im 20. und 21. Jahrhundert, ed. Agnieszka Gąsior, Lars Karl, and Stefan Troebst (Göttingen: Wallstein Verlag, 2014). 
promoted the idea of a Russian conquest of Constantinople and Russian domination in the Balkans. ${ }^{12}$ This set of ideas deepened the existing antagonism between the Russian majority and the Muslim minority in the central cities of the empire as well as between the Russian authorities and the Muslim and non-Russian majority throughout the empire.

Rasulzade, Seydahmet, Munschi, Zeki Velidi Toğan, and Bammate, like many other Muslim intellectuals from the Russian Caucasus and Turkestan were, because of its proximity, fluent in Ottoman Turkish and regularly observed the political and cultural processes in Istanbul at the beginning of the twentieth century. They became involved in revolutionary and political activities in the regions they lived in. Most Azerbaijani intellectuals were also fluent in Persian and engaged in political processes in Iran as well. Linguistic competences played a certain role in making possible the transnational activities of these intellectuals by simplifying, to some extent, the crossing of borders. Additionally, at the turn of the century and particularly after the first Russian revolution of 1905, the languages of the Russian Muslim intellectuals became spaces of transboundary communication with the inhabitants of neighboring countries and empires as well as of the articulation of (shifting) personal identities. The Azerbaijani-Turkish entangled intellectual Ahmet Ağaoğlu, who studied in the 1890 at the Sorbonne, presented himself first as a Persian intellectual. He did this in Paris among French orientalists such as Ernest Renan and James Darmestaetter, who considered Persian culture to be a high culture of the Near and Middle East. But after returning to the Russiandominated Azerbaijani capital Baku at the turn of the century, Ağaoğlu became an ardent pan-Turkist and Azerbaijani nationalist. After his emigration to the Ottoman Empire in 1909 he then shared the ideology of the Young Turks and finally joined the Kemalists after the victory of Mustafa Kemal in Anatolia by promoting the idea of Turkish etatism. ${ }^{13}$

The Russian revolution of 1905 , which was followed by a broad liberalization throughout the empire, made those activities possible. But in 1918-20 their political careers at the peripheries of the former Russian Empire reached their end. The Bolshevik occupation obliged them to leave for Europe, which became a new space for their political activities for the rest of their lives.

12 For more on the reciprocal influence of pan-Slavism and pan-Turkism, see Zaur Gasimov, "Vom Panslavismus über den Panturkismus zum Eurasismus. Die russisch-türkische Ideenzirkulation und Verflechtung der Ordnungsvorstellungen im 20. Jahrhundert," in Post-Panslavismus, ed. Gąsior, Karl, and Troebst, 450-474.

13 See Ufuk Özcan, Ahmet Ağaoğlu ve Rol Değişikliği: Yüzyıl Dönümünde Batılı Bir Aydın (Istanbul: Kitabevi Yayınları, 2010). 
There were numerous dimensions of the discursive levels within this group. Rasulzade, for example, traveled in the 1920 and 1930 s between Turkey, Poland, and France, and wrote for Turkish, Polish, Russian, and French newspapers and journals in Paris and Berlin. Writing in Russian for an émigré journal in Paris he, along with Bammate, took part in a russophone debate in the emigrant community from the former Tsardom. Actually, their intellectual sojourn took place in a multi-dimensional and multicultural milieu of exiles. ${ }^{14}$

\section{Cafer Seydahmet's Public Activities in Interwar Poland}

Cafer Seydahmet was born in 1889 in the Crimea to a religious middle-class Tatar family. After attending a primary school in the Crimea and later a lyceum in Istanbul, Seydahmet was enrolled in the law department of Istanbul University (1909-11). ${ }^{15}$ Afterwards he continued his studies in Paris (1911-13) and St. Petersburg (1913-14). ${ }^{16}$ During the Russian revolution and shortly afterwards Seydahmet engaged himself in local Crimean politics (1917-18), ${ }^{17}$ but after the peninsula was occupied by the Denikin Army and then by the Red Army he left for Istanbul in 1918 and then, in the early 1920s he moved to Le Retour, close to Geneva. He stayed in Poland throughout the 1930s. In the countries of his sojourn he wrote extensively for local newspapers and took part in debates of Russian and non-Russian emigrants from the former Tsardom.

In 1930, the Institute of Oriental Studies (Instytut Wschodni) at the University of Warsaw published Cafer Seydahmet's monograph on the history and current state of the Crimean peninsula. His cooperation with Polish intelligence and scientific institutions, which were backed to a large extent by the Polish secret services and diplomatic circles, was particularly intensive and long; he returned to the so-called Promethean concept elaborated by the Polish authorities in the 1920s. The main target of the Promethean network was to combat Soviet Communism ideologically, and later it was aimed at the dismemberment of the Soviet Union and the restoration of the independent

14 The third space, on the other hand, is merely a space of special encounter between the (former) empire and its (former) colony.

15 For more about Seydahmet, see Inci Bowman, "Cafer Seydahmet Kirimer (1889-1960)." Accessed 21 June 2013: http://www.iccrimea.org/historical/cskirimer.html.

16 In his memoirs Seydahmet describes this period in great detail. See Cafer Seydahmet, Bazı hatıralar [Some memories], (Istanbul: Emel, 1993).

17 For more detail on the political process in the Crimea, see Hakan Kurıml, National Movements \& National Identity among the Crimean Tatars (1905-1916) (Leiden: Brill, 1996). 
states of the Caucasus, Central Asia, and the Ukraine. ${ }^{18}$ In accordance with the Promethean strategy, Polish intelligence and the Ministry of Foreign Affairs organized a supranational and multi-confessional network of Polish politicians, academicians, diplomats, and Caucasian (mostly Azerbaijani, Georgian, and North Caucasian), Ukrainian, Crimean, Kazan Tatar, and Central Asian émigrés who had escaped from Soviet Russia and settled in Europe. This network consisted of Promethean clubs located in Warsaw, Paris, Istanbul, Helsinki, and Berlin. They published several journals in French, Russian, Turkish, and Polish that criticized Soviet policy and Communism. For centuries Poland had enjoyed a special relationship with Muslims, and particularly the Turkish-speaking world and Turkey. In the fourteenth century, a sizeable Tatar colony settled in the territory of the Polish-Lithuanian Commonwealth: it was allowed to build mosques and possess its own religious infrastructure. The Ottoman Empire did not accept the divisions of Poland at the end of the eighteenth century and captured the sympathies of Polish intellectuals and elites. During the Crimean War, Polish politicians and intelligentsia frequently visited Istanbul and forged a common Polish-Ottoman front against Russia.

It was a Polish publishing house that published Seydahmet's monograph on the Crimea and Crimean Tatars. It should be mentioned that the book, Krym. Przeszłość, teraźniejszość i dażenia niepodlegtościowe tatarów krymskich [Crimea. Past, present and independence aspirations of the Crimean Tatars] was a Polish translation of the original French book, La Crimée; passé-présent, revendications des Tatars de Crimée (published in 1921 in Lausanne by Seydahmet), which was aimed at making French readers aware of the historical background and political events in the Crimea. For the Polish edition, Seydahmet expanded the initial version and covered the period of the 1920 s by elucidating the political and cultural activities of the Crimean Tatar communities in Europe and Turkey as well as the persecutions undergone by the Tatars in the Soviet Union. After prefaces by American, ${ }^{19}$ Swiss, ${ }^{20}$ and Polish intellectuals, Seydahmet introduced readers to the basic geography of the peninsula and described its population. "This blessed country has been since ten centuries populated by Tatars, which belong to a strong (Tatar-Mongol) race of

18 For more about the Promethean movement, see Ruch prometejski i walka o przedbudowe Europy Wschodniej (1918-1940) [Promethean movement and the struggle to reshape Eastern Europe (1918-1940)], ed. Marek Kornat (Warsaw: Instytut Historii PAN, 2012).

19 George Herron was an American socialist. He spent several years in Europe and cooperated closely with Muslim intellectuals from Russia and the Soviet Union.

20 Eugene Pittard (1867-1962) was a Swiss professor of anthropology at the University of Geneva. 
Chingiz-Khan."21 Further, he described the etymology of the word Tatar by analyzing the works of European orientalists and travelers. Seydahmet offers a great deal of information on Tatar folklore and customs in this sub-chapter but almost nothing on Islam.

In this context it is quite interesting how Seydahmet described Crimean architecture. "By analysing the Crimean architecture we see that Tatars shaped their own style by combining the Western influence with the Arab, Turkestani, and Istanbul architecture."22 Furthermore, the author referred to the mosques Cuma-Cami in Eupatoria ${ }^{23}$ as well as Khan-Cami in the Crimean capital Bakhchi-Saray. Seydahmet added to his own reflections with quotations from the works of western historians and travelers like François Baron de Tott, Arthur Schnitzler, Louis de Soudak, and Peter Simon Pallas. In the sub-chapter on "Enlightenment and Literacy" Seydahmet mentions the "competence among the Tatars to read the Koran" 24 from the sixteenth century and beyond. The history of the relations between the Crimean Khanate and Poland was a topic that he elucidates in a particular detailed way; ${ }^{25}$ because the book was published in Poland and in Polish, therefore Polish readers were his target group. However, the occupation of the khanate by the Russian Tsardom during the second part of the eighteenth century was the main focus of the monograph, and in its core chapters Seydahmet touches to some extent on the topic of Islam. In the chapter about Russia's "Hostile relations to the clergy" in the Crimea, Seydahmet describes the policy of the Russian authorities on imams in the peninsula. He wrote that mistrust towards the Tatar population was characteristic for Russian authorities and their attitude towards the local imams, particularly those who graduated from theological high schools in Egypt and Turkey, as well as Kazan and Orenburg. Additionally, Seydahmet informs his readers about the Russian authorities' expropriation of land that belonged to mosques and Muslim foundations during the eighteenth century. ${ }^{26}$

In the second part of the nineteenth century St. Petersburg suppressed the resistance of the mountaineers in the northern Caucasus and managed to

21 Dżafer Sejdamet [Cafer Seydahmet], Krym. Przesztość, teraźniejszość $i$ dążenia niepodlegtościowe tatarów krymskich (Warsaw: Instytut Wschodni, 1930) 10.

22 Ibid. 37.

23 Eupatoria or Yevpatoria (Tatar: Kezlev) is a town in the Crimean peninsula with a predominantly Tatar and Karaim (Jewish) population, until the Russian conquest at the end of the eighteenth century.

24 Sejdamet, Krym, 41.

25 Ibid., $48-5^{2}$.

26 Ibid., $55^{-74}$. 
consolidate the empire internally. This coincided with their efforts to homogenize the multi-national and multi-ethnic population of the empire. St. Petersburg was eager to promote Orthodox Christianity in the Protestant and Muslim regions within its own borders. Simultaneously, it cut off contacts of non-Russians to the border regions outside the empire. With regard to the Muslim regions, this policy meant the reduction of any cultural, economic, and political contacts between Russian Muslims and the non-Russian Orient. ${ }^{27}$

According to Seydahmet, in the nineteenth century the Russian authorities were reluctant to issue passports to the Tatars, as they wanted to reduce the number of pilgrims going to Mecca. ${ }^{28}$ In this passage about the Muslim community in Russia, and their interactions and the obstacles to mobility they faced, Seydahmet's intention was not to promote pan-Islamic solidarity. Instead he tried to awaken the sympathies of Polish readers for the cause of an ethnic and religious community governed by a 'hostile regime.' Seydahmet, who spent almost a decade in Poland, had many Polish colleagues in Warsaw and was well acquainted with Polish history, their mentality, and the Polish image of Russia. Most of Polish society, particularly the representatives of the elder generation, had experienced the divisions of Poland and foreign rule, which finally ended in 1918 when the Polish republic was proclaimed. Because of this, Polish readers were particularly sensitive to the victim discourse of the non-Russian intellectuals.

\section{The Anti-communist Agitation of Hilal Munschi in Berlin}

In 1919 the Azerbaijani government sent around one hundred students to Europe, mostly to Germany, France, and Italy for university studies by offering them scholarships. ${ }^{29}$ Hilal Munschi was among those young Azerbaijani students whom the government in Baku sent to Germany. After Azerbaijan was occupied by the Bolsheviks in April 1920, Munschi decided to stay in Germany. He began with vigorous anti-communist propaganda activities. From 1920 he headed the bureau of the Müsavat Party ${ }^{30}$ in Berlin and, from 1923, he coordinated the

27 Daniel Brower, "Russian Roads to Mecca: Religious Tolerance and Muslim Pilgrimage in the Russian Empire," Slavic Review 55, no. 3 (1996): 567-584.

28 Sejdamet, Krym, 66.

29 "Azərbaycan Xalq Cümhuriyəti," in Azarbaycan Xalq Cümhuriyəti Ensiklopediyası, ed. Yaqub Mahmudov (Baku: EA neşriyat1, 2004), 1:75-76.

30 The Müsavat Party was founded in 1911 in Baku by a group of Azerbaijani political activists. During the independence period from 1918 to 1920, Müsavat was among the leading 
Azerbaijani Student Union. Still living in the German capital in 1930 Munschi published a monograph under the title Die Republik Aserbaidschan. Eine geschichtliche und politische Skizze [The Republic of Azerbaijan: A historical and political outline], ${ }^{31}$ in which he depicted the milestones of the Azerbaijani past and present by describing the history, national literature, and culture of Azerbaijan. The main aim of his writings was to present Azerbaijan as a country fighting for freedom and political sovereignty. He endeavored to generate sympathy and support for the Azerbaijani struggle for independence in Europe. In reaction to the ongoing nationalistic rhetoric in Germany, Munschi emphasized the particularistic and nationalistic character of the movement. ${ }^{32}$ Religious aspects did not play a central role in his propaganda work. He described, for example, the Azerbaijani people as having a strong national consciousness and compared them to non-Muslim societies such as Poland, Georgia, and other eastern European countries. He viewed them and Azerbaijan as advanced and civilized societies and described them as part of the family of "Kulturnationen." ${ }^{33}$ In contrast, he characterized the Soviet Union as backward and absolutist.

In his attempt to place Azerbaijan on an equal footing with European countries, Munschi also decried the negative stereotypes of the Orient that he had witnessed during his stay in Berlin. In this sense he rejected the orientalism that he found, for example, in the book Öl und Blut im Orient [Oil and blood in the Orient] written by Essad Bey. ${ }^{34}$ But even in this context Munschi considered the German reader and stressed that this book attacked not only Islamic tradition but national tradition and the religious rites of various societies, including that of the Jews and Christian peoples such as the Georgians, the Armenians, or Russians. Moreover, Munschi points out that the historical truth about Germany was not respected in Essad Bey's book. ${ }^{35}$ Munschi was careful to avoid giving the impression that Islam was an important aspect of Azerbaijani culture; thus he distinguished the country in an essential way from other European cultures.

political parties in the several governments in Baku. After the demise of the republic in 1920, Müsavat continued its existence in the exile, mostly in Iran, Turkey, Poland, and Germany until World War II. During the Perestroika (1985-1991), Müsavat was re-established in Baku. Hilal Munschi, Die Republik Aserbeidschan. Eine geschichtliche und politische Skizze (Berlin: Neudeutsche Verlags- und Treuhand-Gesellschaft, 1930).

32 Ibid., 1.

33 Ibid., 2.

34 Ibid., 3 .

35 Ibid., 4 . 
Munschi pointed out that the important geopolitical position of Azerbaijan had motivated a variety of invaders in numerous conquests. In this context Munschi mentions the Arabs, who "occupied and devastated the country in the seventh century." ${ }^{36}$ According to Munschi, the Arabs governed Azerbaijan for three centuries and spread Islam in the region. It is interesting that he states that "Azerbaijanis were partly Christian, partly Zoroastrian before, but the ethnicity of the population and their language remained throughout the whole period constant: they were and continued to be Turks." ${ }^{37}$ It was not religion, but ethnicity and language that were considered the main factors defining Azerbaijani identity. On the one hand Munschi tried to show the ethnic and racial continuity of Azerbaijanis and their ancestors as Turkish, on the other hand he was also eager to adapt the Azerbaijani nation-building to European narratives. In this context he mentions intensive trade relations with European countries. On the other hand, the rule of Chingis Khan and Batu Khan, for example, is described as a yoke. ${ }^{38}$ About the Persian Shah Aga Mohammed Khan, Munschi writes that his cruel rule coincided with the development of "the Azerbaijani national consciousness that already at the end of the 18th century began to overcome the religious fanatism."39

In his account on Azerbaijani history Munschi mainly focused on the long struggle against Russian domination. Like the main anti-communist narratives of other Muslim intellectuals from the former Russian Empire Munschi describes in detail the Russian invasion of Azerbaijan in the eighteenth century and the annexation of the Muslim khanates in eastern Caucasia during the nineteenth century. Russian rule is described as a violation of Azerbaijani national independence, a menace to peace in the region, and as a suppressive regime. Munschi analyzes social resistance among the Azerbaijanis against the Russian authorities in terms of Kulturkampf and the national struggle by using the example and the terms of nation-building in Central Europe in the nineteenth century.

The Tsarist government always aimed at the suppression of the intellectual struggle of the Azerbaijanis. ...The foundation of any cultural association, including schools in mother tongue [non-Russian], libraries and national theatre were forbidden. The oppression had no limits: even the

\begin{tabular}{ll}
\hline 36 & Ibid., 9. \\
37 & Ibid. \\
38 & Ibid. \\
39 & Ibid., 11.
\end{tabular}


mosques could be built only at an appropriate distance, fixed by law, from the Orthodox churches. ${ }^{40}$

Furthermore Munschi mentions the persecutions of the Muslim clergy by Russian authorities, the suppression of Islam, and the spread of Christianity supported by the Holy Synod. But he softened his argument by writing that even more or less liberal Azerbaijani theologians were persecuted. ${ }^{41}$ At the same time the author also points out that the Azerbaijani media was critical towards the "anti-progressive Muslim clergy" and "confessional discord" (i.e., between Shī'ì and Sunnī). ${ }^{42}$ The satirical journal Mullah Nasreddin, ${ }^{43}$ for instance, fought "against reactionary forces" 44 and the religious fanatism of Persian Muslims. And another journal aimed at the "reform of the Arab alphabet and the woman question." 45 Munschi states that "nearly all the press of Azerbaijan asked for the equality of women"46 and that until 1920 Azerbaijan was the first Muslim country with broad rights for women that were no different than the women's rights of their Christian neighbors.

An example of the transfer of European and particularly German cultural notions can be seen in Munschi's description of Azerbaijani culture. He writes of the great epoch of literary and intellectual development in Azerbaijan in the middle of the nineteenth century and comes to the conclusion that "die großen Dichter und Denker" [the great poets and thinkers] ${ }^{47}$ were the real leaders of the Azerbaijani people. Moreover, Munschi portrays the Azerbaijanis as one of the leading Kulturnationen in the Orient. The Azerbaijani intellectual Mirza Fathali Akhundzade (1812-78), is described as "the greatest dramaturge not only in Azerbaijan but of the whole Islamic Orient."48 Munschi thus promotes the idea of a modernizing cultural mission of Azerbaijanis in the Orient.

\footnotetext{
$40 \quad$ Ibid., 15 .

41 Ibid., 16.

42 Ibid., 23.

43 Mullah Nasreddin was a satiric journal published by Cəlil Məmmədquluzadə, an Azerbaijani writer, from 1906 till 1931. The language of the journal was Azerbaijani and was written first in Arabic, then in Latin, and finally in Cyrillic script. Mullah Nasreddin promoted the ideas of enlightenment among the Muslims of the Caucasus and was critical of the Muslim clergy and to some extent Tsarist policy in the region.

44 Munschi, Die Republik Aserbaidschan, 17.

45 Ibid., 19.

46 Ibid., 20.

47 Ibid., 15 .

48 Ibid.
} 
At the same time Munschi emphasizes the political character of the struggle for independence by the Muslims in the Caucasus. Even with regard to Chechen resistance in the northern Caucasus under the leadership of Shaykh Shāmil, Munschi only speaks of a "political struggle against the Russians," and does not mention his proclamation of jihad against the Russian occupier. ${ }^{49}$ Munschi deliberately used European ideas and categories to attract the attention of German readers to the Azerbaijani cause. He directly appealed to the reader's solidarity and empathy and adapted himself to the German Zeitgeist of the Weimar Republic when he writes: "The loss of the home country awoke the deepest patriotic feelings among all Azerbaijani people. The old spirit of the Khanates disappeared. The [Azerbaijani] nation feels united in the struggle against the northern enemy." 50

Like Seydahmet, Munschi adapted his text to the public it was written for. The argumentation and the choice of symbols and codes were selected deliberately. Islam was mentioned as an important distinction between Azerbaijanis and Russians, and to some extent as a source of civilization, theological discourse, and architecture. At the same time, both authors affirmed their nations' Europeanness and sense of belonging to the progressive community by depicting their national past by using the narative of European history.

\section{Zeki Velidi Toğan's Speech in Budapest}

Born in central Russia, Zeki Velidi Toğan taught at a traditional madrasa in Kazan, accompanied Russian orientalists from St. Petersburg University as interpreter during their excavations in Central Asia, and finally graduated in 1935 from the University of Vienna. He became an outstanding Turkish linguist and historian. Concurrent with his scientific work, Toğan was quite active as an advocate of Turkestani rights in Europe. In this context the presentation he delivered in Budapest in 1930 is of particular interest. His speech was published as a short brochure under the title Die gegenwärtige Lage der Mohammendaner Russlands [The present situation of the Muslims of Russia] in the same year. Zeki V. Toğan described the territories of Russian Tsardom and the Soviet Union inhabited by Muslims eastwards and westwards of the Caspian Sea, and pointed out that both Central Asia and Azerbaijan had been important

49 Ibid., 14.

$5^{\circ}$ Ibid., 14. 
cultural centers of Asia even before the Russian conquest. ${ }^{51}$ Like Munschi and Seydahmet, Toğan demonised the Russians and called Bolshevism a "destructive and cruel ideology." The narrative of Velidi Toğan was, however, quite ambiguous. On the one hand he sharply criticized Communist rule and its oppressive policy towards the Muslim community, on the other hand, he was, to some extent, optimistic about the future of Islam in the Soviet Union:

The fundament[als] of Islam as a religion and cultural power suffered a heavy strike under Bolshevik rule. The madrasas and the Sharia courts were closed. The fanatism of the clergy has suffered dramatically. Nevertheless the acceptance of a new religion or the revival of the preIslamic religion in Muslim Russia and other countries of the Orient is out of the question. Islam experienced a crisis but this concerned only its clerical traditions. ...Islam will only survive as a religion in a genuine spiritual sense. Perhaps it will be exactly the Bolshevik suppression that supports a new recovery of Islam. While Islam was suppressed, the Russian Muslims however hold on to their religion. ${ }^{52}$

Like Munschi, Toğan was quite critical of the Muslim clergy. At the same time neither the rituals of Islam nor the debate about its virtues were emphasized in his speech. The main aim of his presentation, delivered to an audience of orientalists and Turkologists, was to gain empathy among the Hungarians for the Turkestani cause. Toğan stressed the Turkishness of the Muslims in Russia and tried to instrumentalize the pan-Turanian ideas that were widespread in Hungary at that time. ${ }^{53}$

\section{Rasulzade's Writing in Poland}

Mehmed Emin Rasulzade was born and grew up in Baku during the oil boom at the turn of the century. Educated in a Russian-Tatar school in the Christian dominated, industrial metropolis of the Russian Caucasus, Rasulzade became an ardent socialist; he was soon persecuted by the Tsarist authorities for his political activities and had to escape to Persia in 1908. There he co-founded the

\footnotetext{
51 Validi Ahmedzeki [Zeki Velidi Toğan], Die gegenwärtige Lage der Mohammendaner Russlands (Budapest: V. Ahmedzeki, 1930), 3.

$5^{2}$ Ibid., 16.

53 See Joseph Kessler, Turanism and Pan-Turanism in Hungary 1890-1945 (Berkeley: University of California Press, 1967).
} 
socialist movement among Iranian intellectuals by editing the newspaper Irane-Nou. Rasulzade settled in Istanbul in 1911, again for political reasons, but was permitted to return to Baku after the amnesty in 1913. From 1918 to 1920 Rasulzade headed the Azerbaijani parliament, until the republic was occupied by the Bolsheviks. In the early 1920s he was a political exile, first in Turkey, and then in Poland from 1929.

In 1938, the Warsaw-based publishing house Azerbejdżańskie wydawnictwo narodowe [Azerbaijani national edition] published Rasulzade's monograph, Azerbajdżan w walce o niepodlegtość [Azerbaijan in struggle for independence]. The aim of the publication was to inform Polish readers about Azerbaijan, its geography, history, and culture. The author explains the etymology of the name Azerbaijan by analyzing the different theories of Russian and European orientalists, Arab and Azerbaijani historians. He describes the geography and population of Azerbaijan. The latter consists of Azerbaijani Turks, Rasulzade wrote, who were Muslims, and made up 75 percent of the population. ${ }^{54}$

Like Hilal Munschi, Rasulzade emphasized that "Azerbaijanis played an outstanding role in Persian and Turkish culture. Two of seven classic Persian poets, Nizami and Khagani, were originally from Azerbaijan, from Ganja and Shirvan," ${ }^{55}$ noted Rasulzade. Next to this text the author included a photo of the Shirvanshah Palace in downtown Baku and the pre-Islamic Zoroastrian temple Ateshgah in the suburbs of the Azerbaijani capital. In his short overview on the history of Azerbaijan, Rasulzade mentions the Islamization of the eastern Caucasus and Persia only briefly, though historically, it had a huge impact on the development of Azerbaijani culture. Writing about the ancient states in the eastern Caucasus, like the pre-Islamic Caucasian Albania ${ }^{56}$ and Media, Rasulzade stressed that the elites of Albania and its Sassanid rulers were Christian. ${ }^{57}$ The Arabs who conquered and Islamized the region are

54 Mehmed Emin Resul-Zade [Mehmed Emin Rasulzade], Azerbajdżan w walce o niepodlegtość (Warsaw: Azerbejdżańskie wydawnictwo narodowe, 1938), 26.

55 Ibid., 28.

$5^{6}$ Caucasian Albania was an ancient state and society of Caucasian and Iranian ethnic groups in the territory of modern Azerbaijan and northern Iran on the Caspian Sea shore. Albania was Zoroastrian and later Christian; after the invasion of Arabs to the Caucasus, some of its population became Muslim. In Persian and Arabic sources, Albania was called Arran. For more on Caucasian Albania see M.L. Chaumont, "Albania: An Ancient Country in the Caucasus," accessed 19 December 2013: http://www.iranicaonline.org/articles/ albania-iranian-aran-arm. 
mentioned in the same chapter, ${ }^{58}$ though Rasulzade did not write about the transfer of Islamic culture and religion. Like Toğan and Munschi, in several sub-chapters Rasulzade points to the animosity between Azerbaijanis and Russians, which he traces back to a twelfth-century Russian attack against the merchant city of Barda. ${ }^{59}$

Rasulzade uses Islam as the national and cultural identifier of the Muslim inhabitants of the Caucasus. "Muslims were seen in Russia always like 'citizens of the second class.' The population of Turkestan and the Caucasian Muslims were excluded...from military service, in order to prevent them from acquiring any warfare ability," ${ }^{\prime 0}$ Rasulzade claimed. Their religious belonging became a national/ethnic category.

One chapter of the book is devoted to the history of Azerbaijani folk culture. Rasulzade describes popular songs and the oral poetry of Azerbaijanis and stresses their Turkishness, trying to integrate them into the "Turkish speaking world."61 By analyzing the development of Azerbaijani national literature at the beginning of the twentieth century, Rasulzade argues that European national romanticism and to some extent national ideas were transferred from Turkey and became popular in Azerbaijan. As a result of these processes, "the press of Baku, which was initially under the religious-Islamic influence (religijno-islamistyczny ${ }^{62}$ ), was able to elaborate the national-cultural motives." ${ }^{63}$ Again Islam is presented within a national context, not as part of a larger transnational religious idea. ${ }^{64}$ The forerunner of this book was Rasulzade's article, "Rzeczpospolita Azerbajdżańska" [The republic of Azerbaijan], which was published in the Warsaw-based journal Wschód-Orient in 1930. This overview presented Azerbaijan by elucidating its culture, geography, past and present. "Azeris are a modern nation in the very sense of that word. Azerbaijan possesses its own literature, press, theatre, in sum everything that is called a national culture." ${ }^{65}$

In his analysis of the resistance of non-Russian nations against Moscow, Rasulzade differentiated between three groups: the rebels struggling against

\footnotetext{
$5^{8} \quad$ Ibid., $31-36$.

59 Ibid., 34 .

$60 \quad$ Ibid., 45 .

61 Ibid., 48-49.

62 The Polish notion islamistyczny can be translated into English nowadays as 'Islamist.' Rasulzade used it, however, as an adjective derived from the noun 'Islam.'

63 Resul-Zade, Azerbajdżan, 55 .

64 M.E. Ressul-Zade, "Rzeczpospolita Azerbajdżańska," Wschód-Orient 2 (1930): 26.

65 Ibid.
} 
the Bolsheviks, the emigrants outside the Soviet Union, and the opposition inside the Communist Party. Rasulzade emphasized the ethnic, cultural and religious differences between Russia and Azerbaijan. According to him the "Muslim and Turkish population of Azerbaijan"66 was against any ideology that had an all-Russian dimension, such as pan-Slavism or Bolshevism. He classified himself and his compatriots as not aligned with any Russian political party or movement.

\section{Haïdar Bammate's Publishing Activities in Lausanne and Paris}

Born in 1890 in the northern Caucasus to a turkophone Dagestani family, Bammate studied law at the University of St. Petersburg, and then worked for Tsarist authorities in Tbilisi and Kazan. After the Russian revolution he became the Minister of Foreign Affairs of a short-lived North Caucasian Republic of Mountaineers. After the fall of the northern Caucasus, Bammate migrated to France and actively spread anti-Soviet propaganda. He was supported first by Polish intelligence, and later, throughout the 1930s, by German and Japanese intelligence.

In 1919 Haïdar Bammate published in Lausanne a book entitled Le Problème du Caucase. ${ }^{67}$ In the principal chapter of the book Bammate develops the idea of the importance of the Caucasus, and particularly the Muslim Circassians, for Europe, as they serve as a bulwark against Communism. He points out that the Circassians supported Europe in the past by hindering "Asian attacks" coming from the East. In fact, Bammate repeats the arguments of many southeastern European intellectuals at the beginning of the twentieth century; these intellectuals stress the bulwark position of their countries by presenting them as safeguards of Europe against Islam.

In Paris and Berlin from 1934 to 1939 Bammate edited the Russian language journal Kavkaz, which emerged in German and French translation after 1937. This journal critically elucidated the political process in the Soviet Union and therefore contributed to European anti-communist thought. Moreover, the Kavkaz attracted attention for its pro-Turkish and pro-Kemalist point of view, although the Kemalist government in Ankara maintained good relations with

66 M.E. Ressul-zade, "Prądy narodowe w Azerbajdżanie Sowieckim," Wschód-Orient 1-2 (1935): 19 .

67 Haïdar Bammate, Le Problème du Caucase. Extrait de La Revue Politique Internationale $N$ de Novembre-Décembre 1918. Avec une carte ethnographique (Lausanne: La Revue politique interntionale, 1919). 
the Soviet Union. Haïdar Bammate wrote several editorials on the Near East and the historical and cultural bonds between the Caucasus and the Near East. Furthermore, Bammate was interested in the promotion of pan-Caucasian unity and integration. Being eager to involve Christian, especially Georgian and Armenian intellectuals, in his project of Caucasian confederation, ${ }^{68}$ Bammate abandoned other alternative ideas like, for example, pan-Islamic solidarity.

Throughout the 193os and during World War II, Bammate collected material for his long monograph on Islam. In 1946 his life's work was published in Lausanne under the title Visage de l'Islam. ${ }^{69}$ The aim of his book was to offer an overview of "the spiritual and intellectual values of Islam and to recall his [i.e., Islam's] contribution to the Occident." ${ }^{\prime 0}$ After elaborating on numerous works by French, Spanish, and Russian orientalists, Bammate delivers an interesting narrative of Islam's evolution from the rule of the Umayyad dynasty to World War II, paying particular attention to the development of Persian, Arabic, and Turkish literature, the sciences, and Islamic art. The chapter on art was written by his son Nadjmouddine (1922-85). $\cdot{ }^{71}$ While describing Persian and Arabic poetry, Bammate stresses their influence on European literature, mostly on Spanish and Provencal poetry. Quoting extensively from the works of Ernest Renan and other French orientalists, Bammate simultaneously criticizes some of the stereotypes about the Near East and Islam in their works. Bammate's 500-page book offers a profound overview on the history of Islam, its contribution to world culture and civilization "au grand public," for a broad public. Bammate pleads for Christian-Muslim dialogue. According to him, there is a strong similarity between the moral virtues and values of the Christian and Islamic civilizations. The expanded version of Visages de l'Islam was republished in 1959 and was well-received among Francophone Algerian ${ }^{72}$ nationalists and by readers in Turkey. ${ }^{73}$

68 Gaidar Bammat, "Nashi zadachi," Kavkaz (Le Caucase) Organ nezavisimoi natsional'noi mysli 1 (1934): $3^{-5}$.

69 Bammate, Visages de l'Islam.

$70 \quad$ “...il nous a paru utile de soumettre aux lectuers un apercu rapide mais assez varié des valeurs spirituelles et intellectuelles de l'Islam et de rappeler son apport à l'Occident." Bammate, Visages de l'Islam, xiii.

71 The chapter was published in the same year as a separate booklet, also in Lausanne.

72 Sadek Sellam, "Le FLN vu par l'écrivain Malek Bennabi (1905-1973): Les relations malaisées d'un penseur non conformiste avec le pouvoir algérien naissant," Guerres mondiales et conflits contemporains 4, no. 208 (Oct.-Dec. 2002), 136; DOI: 10.3917/gmcc208.0133.

73 Throughout the 1960 and 1970s, two different translations of Visages de l'Islam were published in Istanbul and Ankara. 


\section{Conclusion}

Cafer Seydahmet, Zeki Velidi Toğan, Hilal Munschi, Haïdare Bammate, and M. Rasulzade like many other Azerbaijani, north Caucasian, and Tatar intellectuals living in exile in interwar Europe conducted anti-communist propaganda activities in France, Poland, and Germany. They wrote for a variety of European media and published books on the history and the socio-political situation of their countries of origin. They were eager to make European readers aware of the culture, the recent developments, and the current political problems in the Soviet Caucasus and the Crimea, and Islam played a significant role in their argumentation. Because they were based in Christian countries and addressing primarily Europeans, these non-Russian Muslim émigrés were quite cautious with regard to their contributions on Islam in the European media during the 1920s. Perhaps this was an attempt to avoid any impression of being 'religious Muslims' among European intellectuals and politicians. It can be freely assumed that these Azerbaijani and Tatar intellectuals presented themselves and their countries of origin as less Islamic than they were in reality. The aim of these anti-communist émigrés was to obtain European support in their confrontation with the Soviet Union; they clearly shared the impression that the West would be reluctant to support Islamic societies.

In this context it is useful to mention the similarities between the texts written by these Muslim intellectuals in exile in Europe and Turkey in the interwar period. Islam, its rituals, customs, traditions, and institutions were only depicted marginally, even in Turkish publications, which emerged in Istanbul during the 1920 s and 1930s. This was because of Mustafa Kemal Atatürk's rigorous secularist policies during this period. The differences in the Turkish texts written by Seydahmet, Rasulzade, and Zeki Velidi Toğan relates to their appeals to pan-Turkish solidarity and Turkishness, which were much less articulated in the texts they published in Polish, French, and German.

Islam was treated as an essential subject in the books and articles of Rasulzade, Bammate, Munschi, Seydahmet, and Zeki Velidi Toğan, though they belonged to a secular generation of Eurasian intellectuals of Muslim origin, who shared the opinion that nationalism was much more important for the mobilization of their ethnic groups than the idea of a supranational Islamic community (umma). While the representation of Islam in interwar Europe was not a life vocation for these Muslim intellectuals from Russia living in European exile, this changed considerably after World War II. 


\section{Bibliography}

\section{Primary Sources}

Bammate, Haïdar. Le Problème du Caucase. Extrait de La Revue Politique Internationale $N$ de Novembre-Décembre 1918. Avec une carte ethnographique. Lausanne: La Revue Politique Internationale, 1919.

_ [Bammat, Gaidar]. "Nashi zadachi." Kavkaz (Le Caucase) Organ nezavisimoi natsional'noi mysli 1 (1934): 3-5.

— [Bammate, Haidar/Georges Rivoire]. Visages de l'Islam. Lausanne: Payot, 1946. Essad Bey, Mohammed. Eine Biographie. Berlin: Kiepenheuer, 1932.

Munschi, Hilal. Die Republik Aserbaidschan. Eine geschichtliche und politische Skizze. Berlin: Neudeutsche Verlags- und Treuhand-Gesellschaft, 1930.

Resul-Zade, Mehmed Emin [Mehmed Emin Rasulzade]. Azerbajdżan w walce o niepodlegtość [Azerbaijan in struggle for independence]. Warsaw: Azerbejdżańskie wydawnictwo narodowe, 1938.

—. "Prądy narodowe w Azerbajdżanie Sowieckim." Wschód 1-2 (1935): 18-33.

"Rzeczpospolita Azerbajdżańska." Wschód 2 (1930): 26-29.

Seydahmet, Cafer. Bazı hatıralar. Istanbul: Emel, 1993.

[Sejdamet, Dżafer]. Krym. Przeszłość, teraźniejszość i dążenia niepodlegtościowe tatarów krymskich [Crimea. Past, present and independence aspirations of the Crimean Tatars]. Warsaw: Instytut Wschodni, 1930.

Validi Ahmedzeki [Zeki V. Toğan]. Die gegenwärtige Lage der Mohammendaner Russlands. Budapest: V. Ahmetzeki, 1930.

\section{Research Literature}

“Azərbaycan Xalq Cümhuriyəti." In Azərbaycan Xalq Cümhuriyati Ensiklopediyası, edited by Yaqub Mahmudov et al. Baku: EA nəşriyyatı, 2004.

Bowman, Inci. "Cafer Seydahmet Kirimer (1889-1960)." Online: International Committee for Crimea. Accessed 21 June 2013: http://www.iccrimea.org/historical/ cskirimer.html.

Brower, Daniel. "Russian Roads to Mecca: Religious Tolerance and Muslim Pilgrimage in the Russian Empire." Slavic Review 55, no. 3 (1996): 567-584.

Gasimov, Zaur. "Bolshevik Post-Colonialism, Eurasian Perspective and Entangled Intellectuals. Russian Debates on Spengler in the Interwar Period." In Oswald Spengler als europäisches Phänomen. Der Transfer der Kultur- und Geschichtsmorphologie im Europa der Zwischenkriegszeit 1919-1939, edited by Zaur Gasimov and Carl A. Lemke Duque, 67-83. Göttingen:V\&R, 2013.

and Wiebke Bachmann. "Für nationale Ehre, Freiheit und Selbständigkeit! Die publizistische Aktivität der aserbaidschanischen Exilanten in Berlin in der 
Zwischenkriegszeit." In Brücken bauen-Analysen und Betrachtungen zwischen Ost und West. Festschrift für Leonid Luks zum $6{ }_{5}$ Geburtstag, edited by Jürgen Zarusky, et al., 277-294. Stuttgart: Ibidem Verlag, 2012.

. "Vom Panslavismus über den Panturkismus zum Eurasismus. Die russischtürkische Ideenzirkulation und Verflechtung der Ordnungsvorstellungen im 20. Jahrhundert." In Post-Panslavismus. Slavizität, Slavische Idee und Antislavismus im 20. und 21. Jahrhundert, edited by Agnieszka Gąsior, Lars Karl, and Stefan Troebst, 450-474. Göttingen: Wallstein Verlag, 2014.

Kazemzade, Firuz. The Struggle for Transcaucasia, 1917-1921. Westport, ст: Hyperion, 1981.

Kessler, Joseph. Turanism and Pan-Turanism in Hungary 1890-1945. Berkeley: California University Press, 1967.

Kurıml, Hakan. National Movements \& National Identity among the Crimean Tatars (1905-1916). Leiden: Brill, 1996.

Kornat, Marek, ed. Ruch prometejski i walka o przedbudowę Europy Wschodniej (1918-1940) [Promethean movement and the struggle to reshape Eastern Europe (1918-1940)]. Warsaw: Instytut Historii PAN, 2012.

Özcan, Ufuk. Ahmet Ağaoğlu ve Rol Değişikliği: Yüzyıl Dönümünde Batılı Bir Aydın. Istanbul: Kitabevi Yayınlan, 2010.

Rutherford, Jonathan. "The Third Space. Interview with Homi Bhabha." In Identity: Community, Culture, Difference, edited by Jonathan Rutherford, 207-221. London: Lawrence and Wishart, 1990.

Sellam, Sadek. "Le FLN vu par l'écrivain Malek Bennabi (1905-1973): Les relations malaisées d'unpenseur non conformiste avec le pouvoir algérien naissant." Guerres mondiales et conflits contemporains, 4, no. 208 (October-December 2002): 133-150. DOI: 10.3917/gmcc.208.0133.

Weeks, Theodore R. "Russification/Sovietization.” In European History Online (EGo). Mainz: Institute of European History (IEG ), 2010. Accessed 2 December 2013: http:// ieg-ego.eu/en/threads/models-and-stereotypes/russification-sovietization. 